\title{
ИСПОЛЬЗОВАНИЕ МЕТОДА ОКИСЛИТЕЛЬНОГО ГЕМОЛИЗА ЭРИТРОЦИТОВ В КОМПЛЕКСНОЙ ОЦЕНКЕ АНТИОКСИДАНТНОЙ АКТИВНОСТИ ПРИРОДНЫХ И СИНТЕТИЧЕСКИХ СОЕДИНЕНИЙ IN VITRO
}

\author{
О.Г. Шевченко \\ Институт биологии Коми НЦ УрО РАН, \\ 167982, Россия, Сыктывкар, ул. Коммунистическая, 28.
}

DOI: 10.19163/MedChemRussia2021-2021-149

E-mail: shevchenko@ib.komisc.ru

Исследование антиоксидантной активности природных и синтетических соединений представляет интерес с точки зрения поиска перспективных лекарственных агентов для терапии широкого спектра социально-значимых заболеваний. Корректная оценка антиоксидантной активности требует сочетания репрезентативных модельных систем различной степени сложности.

Удобной и доступной клеточной моделью для исследований in vitro являются эритроциты крови млекопитающих, в частности, широкое применение нашел метод окислительного гемолиза эритроцитов. Исследования на эритроцитах, включающие анализ выживаемости клеток, интенсивность окисления мембранных липидов и гемоглобина, а также деградацию гема в условиях острого окислительного стресса, должны дополняться иными методами, позволяющими оценить молекулярные механизмы антиоксидантной активности. К ним относится анализ антирадикальной активности соединений, способности хелатировать ионы переходных металлов, ингибировать процессы перекисного окисления липидов в гетерогенных органических субстратах, содержащих липиды животных тканей. Результаты комплексных исследований свидетельствуют о достаточно сложной зависимости между данными, полученными различными методами в клеточной и неклеточной модельных системах. Данный подход, основанный на сочетании нескольких тест систем, включая клеточную, успешно апробирован нами при оценке антиоксидантной и мембранопротекторной активности соединений различной структуры. С результатами исследований, выполненных преимущественно совместно с сотрудниками Института химии Коми НЦ УрО РАН, можно ознакомиться в работах [1-7].

\section{Литература}

1. E.V. Buravlev, O.G. Shevchenko, A.V. Kutchin, Bioorg. Med. Chem. Lett., 2015, 25, 826-829.

2. E.V. Buravlev, O.G. Shevchenko, A.A. Anisimov et al., Eur.J. Med.Chem., 2018, 152, 10-20.

3. A.V. Samet, O.G. Shevchenko, Rusak V.V., et al., J. Nat. Prod., 2019, 82, 1451-1458.

4. I.S. Martakov, O.G. Shevchenko, M.A. Torlopov et al., J. Inorg. Biochem., 2019, 199, 110782.

5. I.S. Martakov, O.G. Shevchenko, J. Inorg. Biochem., 2020, 210, 111168.

6. M. A. Torlopov, O.G. Shevchenko., I.Yu. Chukicheva et al., React. Funct. Polym., 2020, 156, 104740.

7. E.V. Buravlev, O.G. Shevchenko, K.Yu. Suponitsky, Chem. biodivers., 2021, 18, e210022.

$$
-149-
$$

